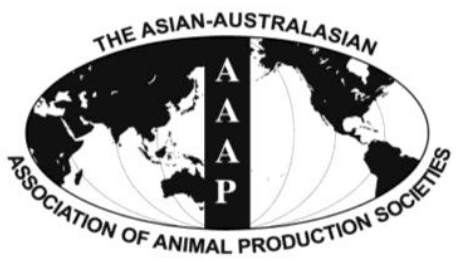

Asian Australas. J. Anim. Sci.

Vol. 26, No. 5 : 654-660 May 2013

http://dx.doi.org/10.5713/ajas.2012.12510

www.ajas.info

pISSN 1011-2367 elSSN 1976-5517

\title{
Effect of Oral Administration of Intact Casein on Gastrointestinal Hormone Secretion and Pancreatic $\alpha$-Amylase Activity in Korean Native Steer
}

\author{
S. B. Lee ${ }^{1, a}$, C. W. Choi ${ }^{2, a}$, Y. C. Jin ${ }^{3}$, T. Wang, K. H. Lee, M. B. Ku ${ }^{1}$, J. H. Hwang, \\ K. H. Kim ${ }^{4}$, R. S. A. Vega ${ }^{5}$ and H. G. Lee* \\ Department of Animal Science and Technology, College of Animal Bioscience and Technology, \\ Konkuk University, Seoul 143-701, Korea
}

\begin{abstract}
Three Korean native steers $(779 \pm 24 \mathrm{~kg})$ fitted with duodenal cannulas were used in a $3 \times 3$ Latin square design to investigate the influence of oral administration of soluble proteins, intact casein (IC) and acid hydrolyzed casein (AHC), on gastrointestinal hormone $(\mathrm{GIH})$ secretion in the blood and pancreatic $\alpha$-amylase activity in the duodenum. Oral treatment consisted of a basic diet (control), IC (C+100\% protein), or AHC (C+80\% amino acid, $20 \%$ peptide) for $21 \mathrm{~d}$. Blood and duodenum samples were collected for measurement of serum GI hormones, and pancreatic $\alpha$-amylase activity was determined at 900, 1030, 1330, 1630, and 1930 h after feeding on d 21 of treatment. The levels of serum cholecystokinin (CCK) and secretin in the IC treatment group were higher compared to the other treatment groups $(\mathrm{p}<0.05)$. In addition to the changes in CCK and secretin levels upon IC treatment, the pancreatic $\alpha$-amylase activity in the duodenum was higher in the IC group compared to the control diet group ( $\mathrm{p}<0.05)$. The response of serum ghrelin to IC and AHC treatment was in accordance with the response of serum secretin. The level of peptide fragments flowing in the duodenum was higher in the IC treatment group than the other treatment groups $(\mathrm{p}<0.05)$. In conclusion, this study demonstrated that an increase in duodenal CCK and secretin upon IC oral administration increased pancreatic $\alpha$-amylase secretion. In addition, ghrelin may be associated with GI hormone secretion in Korean native steers. (Key Words: Secretin, Cholecystokinin, Ghrelin, $\alpha$-Amylase, Korean Native Steer)
\end{abstract}

\section{INTRODUCTION}

Ruminants have evolved as cellulose fermenters, and it has long been thought that they possess a limited intestinal starch digestion by pancreatic $\alpha$-amylase. Although the

\footnotetext{
* Corresponding Author: H. G. Lee. Tel: +82-2-450-0523, Fax: +82-2-455-1044, E-mail: hglee66@konkuk.ac.kr

${ }^{1}$ Department of Animal Science, Pusan National University, Miryang, Gyeongnam 627-706, Korea

${ }^{2}$ Department of Animal Resources, Deagu University, Gyeongsan, Gyeongbuk 712-714, Korea.

${ }^{3}$ Department of Animal Science, College of Animal Science and Veterinary Medicine, Jilin University, Changchun 130062, China

${ }^{4}$ Department of Nutrition and Physiology, National institute of animal science, RDA, Suwon 441-706, Korea.

${ }^{5}$ Animal and Dairy Sciences Cluster, College of Agriculture, U.P. Los Baños, College, Laguna, Philippines.

${ }^{\text {a }}$ S.B. Lee and C.W. Choi were equally contributed to this research.

Submitted Sept. 18, 2012; Accepted Nov. 15, 2012; Revised Feb. 14, 2013
}

majority of dietary starch is digested in the rumen, about 35 to $60 \%$ of dietary starch is degraded in the small intestine. However, of this fraction, about 35 to $50 \%$ escapes small intestinal digestion (Harmon and Taylor, 2005). Thus, researchers have made efforts to improve the digestibility of intestinal starch. Taniguchi et al. (1995) suggested that a protein source can somewhat improve starch digestion in the bovine small intestine. Richard et al. (2003) reported that abomasal infusion of starch with casein increases starch degradability in the small intestine of steers. These results show that starch digestion by $\alpha$-amylase in the small intestine can be manipulated nutritionally, particularly by soluble protein.

Generally, $\alpha$-amylase secretion from the pancreas is induced by GIH like cholecystokinin (CCK), secretin, and ghrelin. CCK secretion from the small intestine is triggered by amino acids and fatty acids in the chyme. The effects of CCK include decreased stomach and intestinal motility, 
decreased meal size, and increased pancreatic $\alpha$-amylase levels. The secretion of secretin from the duodenum is induced by the arrival of acidic chyme from the stomach. The receptors of CCK and secretin are located in the pancreas, which potentiates CCK-induced pancreatic $\alpha$-amylase secretion. Ghrelin is a peptide hormone which can increase blood CCK levels in rats after injection (Itoh et al., 2006). However, the relationship between GIH and pancreatic $\alpha$-amylase secretion in ruminants and protein types is not well understood. Therefore, this study was conducted to determine the effects of oral administration of the soluble protein types, intact casein (IC) and acid hydrolyzed casein (AHC), on GIH secretion in the blood and pancreatic $\alpha$-amylase activity in the duodenum of the Korean native steer.

\section{MATERIAL AND METHODS}

\section{Animals and diet}

Three Korean native steers (mean initial body weight $779 \pm 24 \mathrm{~kg}$ ) were used in this experiment. Under general anesthesia, the animals were surgically prepared with fitted cannulas in the pancreatic pouch and duodenum for quantitative collection of the pancreatic juice, as described by Swanson et al. (2002). The animals were then housed individually in $3 \times 3.2 \mathrm{~m}$ pens with concrete floors in a temperature and light controlled $\left(23^{\circ} \mathrm{C}\right.$ and $16 \mathrm{~h}$ of light $/ 8 \mathrm{~h}$ of dark, respectively) room with water available at all times as well as a trace-mineralized salt block. Steers were weighed before each treatment period. The basal forage diet was composed of rice straw $(31.3 \%)$ and concentrate $(68.7 \%)$ on an as-fed basis. Based on \% DM basis the concentrate mix was composed of corn $(50.8 \%)$, wheat bran $(38.0 \%)$, soybean meal $(3.0 \%)$, rapeseed meal $(2.0 \%)$, molasses $(2.0 \%)$, limestone $(1.5 \%)$, salt $(0.4 \%)$ and vitamin and minerals $(0.3 \%)$. The daily feed allowance was twice a day, at 900 and $1700 \mathrm{~h}$ for $11 \mathrm{~d}$ before treatment. Chemical composition of the concentrates is shown in Table 1, and the DM (\%) composition of Control, IC, and AHC was similar. Metabolic energy intake was allowed at 1.2 times the maintenance requirements for a Hanwoo steer (NIAS 2007). Chromic oxide was added into the concentrates at $0.2 \%$.

Table 1. Proximate analysis of experimental feeds*

\begin{tabular}{lrrrr}
\hline & Rice straw & Concentrate & $\begin{array}{r}\text { Intact } \\
\text { casein }\end{array}$ & $\begin{array}{c}\text { Acid } \\
\text { hydrolysates }\end{array}$ \\
\hline DM (\%) & 93.56 & 88.13 & 92.94 & 92.28 \\
CP (\% of DM) & 4.45 & 14.66 & 87.11 & 49.13 \\
EE (\% of DM) & 1.34 & 3.74 & 3.68 & 0.10 \\
CF (\% of DM) & 37.04 & 5.86 & 1.00 & 0.37 \\
Crude ash & 11.90 & 5.12 & 5.24 & 44.93 \\
$(\%$ of DM) & & & & \\
\hline
\end{tabular}

* The water, vitamins and mineral block was available at all times.

\section{Experimental design and treatment}

Steers were randomly allotted to oral treatment groups within a $3 \times 3$ Latin square design. Oral treatments consisted of either basic diet $(31.3 \%$ rice straw $+68.7 \%$ concentrate), IC (supplementation of IC ( $100 \%$ protein) at $0.24 \%$ in basic diet), or AHC (supplementation of AHC (80\% Amino acid, $20 \%$ Peptide) at $0.46 \%$ in basic diet). Treatments were provided for three periods that each consisted of $21 \mathrm{~d}$ for a total of $63 \mathrm{~d}$.

\section{Sample collection}

Serum and duodenal fluids sampling: Jugular blood and duodenum samples were collected and analyzed for serum GI hormone levels and $\alpha$-amylase activity at 900, 1030, 1330, 1630, and $1930 \mathrm{~h}$ after feeding on $\mathrm{d} 21$ of the experiment. Jugular blood samples $(15 \mathrm{ml})$ were collected into serum syringes and immediately centrifuged $(3,000$ $\mathrm{rpm}, 15 \mathrm{~min}$ ) to obtain the serum. Aliquots of the serum were then placed into separate tubes $(1.5 \mathrm{ml})$ and frozen $\left(-80^{\circ} \mathrm{C}\right)$ until analyzed. Duodenum fluids were collected according to time zones through the canula connected to duodenum. Collected duodenum fluids were then strained through four layers of cheesecloth under a flux of $\mathrm{CO}_{2}$ to remove feed particles; samples were kept frozen $\left(-80^{\circ} \mathrm{C}\right)$ until analyzed. Rumen and omasal digesta (OD) were sampled at 1.0 or $1.5 \mathrm{~h}$ intervals during a $12 \mathrm{~h}$ feeding cycle, sequentially centrifuged to eliminate microbes, treated with trichloroacetic acid, and then centrifuged. Omasal digesta samples were collected from the omasal canal by means of a plastic tube (14 mm i.d.) connected to a pump according to procedures outlined by Huhtanen et al. (1997), with the exception that the three-way stainless steel ball valve controlling alternating pressure and vacuum in the omasal sampling device was replaced by solenoid valves controlled by an adjustable relay. In addition, the tube of the sampling device was larger (14 vs $9.5 \mathrm{~mm}$ i.d).with $0.5 \mathrm{~kg}$ weight inserted into the abomasum to secure the sampling device in the omasum.

\section{Laboratory analysis}

Immunoassay method for establishment of the GIH Ghrelin, Secretin, and CCK-8 in bovine serum: A homologous test was conducted to determine first the crossreactivity of $\mathrm{Ab}$ combining site provided by the kit. BLAST peptide similarity search was performed using NCBI and ExPasy SIB BLAST Network Service (Table 2). In addition, The Hanwoo steer serum serial dilution was conducted to determine parallelism of the EIA assay Kit having ghrelin (human), secretin (porcine, bovine) and CCK (human, rat, mouse) standards in relation to bovine serum serial dilution. The results showed parallelism about the standard curve (Figure 1). The identification of the appropriate dilution 
Table 2. BLAST peptide similarity between human and bovine ghrelin, secretin and CCK-8

\begin{tabular}{lllc}
\hline Hormone & Species & \multicolumn{1}{c}{ Sequence } & Similarity (\%) \\
\hline Ghrelin & Human & GSSFLSPEHQRV & 83.3 \\
& Bovine & GSSFLSPEHQKL & 100.0 \\
Secretin & Bovine & HSDGTFTSEL SRLRDSARLQ RLLQGLV & 100.0 \\
& Bovine & HSDGTFTSEL SRLRDSARLQ RLLQGLV & \\
\hline \multirow{2}{*}{ CCK-8 } & Human & DYMGWMDF & \\
& Bovine & DYMGWMDF
\end{tabular}

value is shown in Figure 1. We selected the dilution value that had the optical density (OD) located in the middle of the standard curve. The appropriate dilution values and concentrations are shown separately as the following: Ghrelin ( $4 \times$ dilution, 0.1 to $0.3 \mathrm{ng} / \mathrm{ml})$, Secretin $(2 \times$ dilution, 0.2 to $0.8 \mathrm{ng} / \mathrm{ml}$ ), CCK-8 ( $2 \times$ dilution, 0.2 to $1.5 \mathrm{ng} / \mathrm{ml}$ ). Sensitivities for the Ghrelin, Secretin and CCK were 0.1 $\mathrm{ng} / \mathrm{ml}, 0.15 \mathrm{ng} / \mathrm{ml}$ and $0.05 \mathrm{ng} / \mathrm{ml}$, respectively, and the intra- and inter-assay coefficients of variation $(\mathrm{CV})$ for these were 9.8 and $14.9 \%, 16.9$ and $13.4 \%$, and 10.3 and $15.6 \%$, respectively.

Analysis of GIH in jugular serum and soluble protein concentration in gastrointestinal fluids: The serum levels of ghrelin, CCK, and secretin were determined by enzyme immunoassay: ghrelin (EK-031-30), secretin (EK-067-05), and CCK-8 (EK-069-04) (Phoenix Pharmaceuticals, USA) using a secondary antibody-coated plate. Insulin level was determined using a Bovine Insulin ELISA Kit (catalog No. 10-1201-01) (Mercodia, Sweden). Glucose was analyzed according to the glucose-HK-G6PDH method.

Liquid flow from the rumen and small intestine was determined using LiCoEDTA as a marker; whereas soluble non-ammonia $\mathrm{N}$ (SNAN) entering the omasum was fractionated into microbial and non-microbial $\mathrm{N}$ (defined as dietary N) using $15 \mathrm{~N}$. Different SNAN fractions were measured by using ninhydrin assay (NHA). Specifically, the level of free-amino acid (AA) $\mathrm{N}$ was measured in the supernatant without acid hydrolysis, whereas the level of peptide $\mathrm{N}$ was measured after hydrolysis of the supernatant minus free AA N. Soluble protein $\mathrm{N}$ was measured after hydrolysis of the tricholoroacetic acid precipitate.

$\alpha$-Amylase activity examination in duodenum fluids of exocrine pancreas: The $\alpha$-amylase activity of duodenal fluid secreted from the exocrine gland of the pancreas was measured using an EnzyChrom ${ }^{\mathrm{TM}} \alpha$-amylase Assay Kit (ECAM-100, BioAssay Systems, USA).

\section{Statistical analysis}

The analysis of variance (ANOVA) used SPSS $14.0 \mathrm{~K}$ for Windows, and the treatment mean comparison used student t-test when ANOVA declared significant differences at $\mathrm{p}<0.05$.

\section{RESULTS AND DISCUSSION}

\section{Relationship between $\alpha$-amylase activity and GIH}

As shown in Figure 2, the secretion of the serum GIH ghrelin, CCK, and secretin was closely related to $\alpha$-amylase activity in the duodenum. In the same period, the levels of GI hormones and $\alpha$-amylase activity were the highest in the IC group. Specifically, the levels of CCK, secretin, and duodenum $\alpha$-amylase activity in the IC group were significantly higher than other treatment groups $(\mathrm{p}<0.05)$. However, there was no effect of IC or AHC treatment on serum ghrelin and insulin levels in the steers. In addition, the response of serum ghrelin to IC and AHC treatment was in accordance with the response of serum secretin.

Generally, CCK induces a decrease in the viscosity of
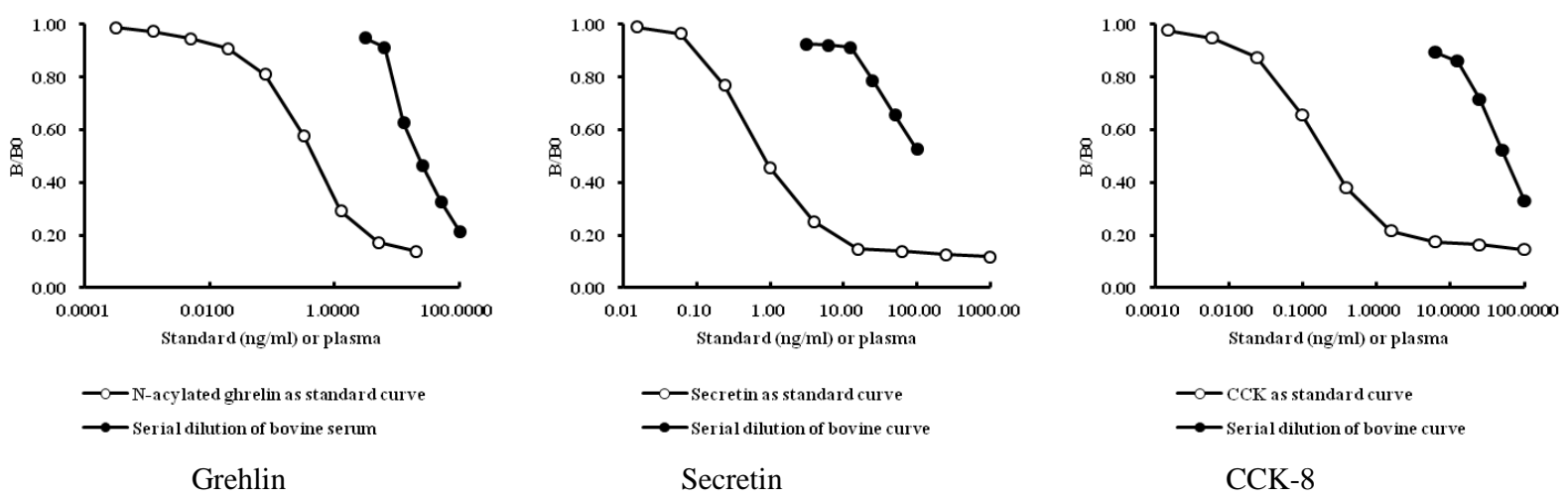

Figure 1. Cross reactivity test of Hanwoo steer serum serial dilution parallel test with human ghrelin, secretin and CCK-8 standard curve. 

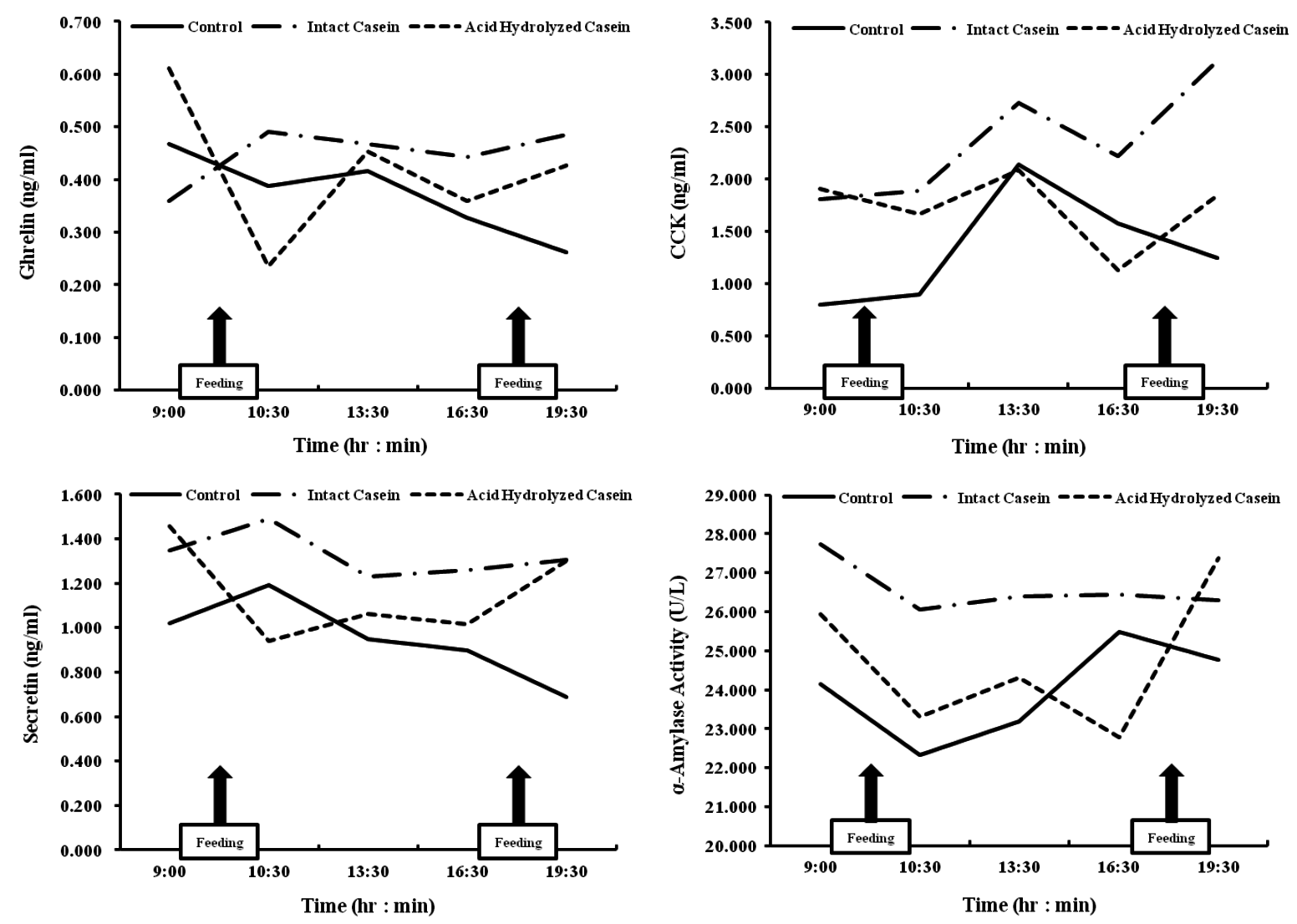

Figure 2. Relationship between serum GI hormones and duodenum $\alpha$-amylase of Korean native steers fed control, IC and AHC with ghrelin, secretin and CCK-8 having human, porcine and rat equivalent standards.

intestinal content, activates bicarbonate secretion into the intestine, and increases the efficiency of secretin (Meyer et al., 1971). Further, pancreatic endocrine secretion is sensitive to CCK and secretin in ruminants (Croom et al., 1992). Secreted CCK from the fundus of the small intestine is known to stimulate pancreatic secretion through the afferent pathway of the vagus nerve (Li and Owyang, 1993; Eastwood et al., 1998). Additionally, long term of administration of $\mathrm{CCK}$ has been found to promote pancreatic growth (Folsch, 1984). Moreover, secretion of pancreatic proteins into the small intestine is stimulated by secretin or secretin+CCK and endogenous stimulant (Lin et al., 1977; Greenberg et al., 1979; Chance et al., 1981; Langlois et al., 1989). Rausch et al. (1985) reported that the extent to which synthesis of the total pancreatic protein was higher until a maximum of $90 \%$ than a control at $6 \mathrm{~h}$ and 12 $\mathrm{h}$ after secretin injection into the acinar cell of a rat. Moreover, Manso et al. (1989) demonstrated that the secretin administration to mice with acute pancreatitis increases both amylase secretion and the amount of total proteins produced by the pancreas. The CCK secretion in response to fatty acids and proteins increases pancreatic protease levels and activity in the small intestine of rats (Hara et al., 2000). Further, there are many reports on the connection between increased blood plasma CCK in response to protein injection into the small intestine and regulation of secretion in the exocrine gland of the pancreas (Tachibana et al., 1995; Swanson et al., 2004). Therefore, our results demonstrated that an increase in duodenal CCK and secretin levels upon oral administration of IC increased pancreatic $\alpha$-amylase secretion.

\section{Relationship between GIH and flow amount in lower digestive organs}

As shown in Table 3, administration of other soluble proteins resulted in different flow amounts in the lower digestive organ. The amounts of SNAN and peptides in the rumen, omasum and duodenal were significantly higher in the IC and AHC diet groups compared to the control group $(\mathrm{p}<0.05)$. In addition, the amino acid concentration was relatively high in the omasal portions.

The peptide outflow in the ruminal, omasal and duodenal of animals in IC and AHC groups was significantly higher than that of the control; however, the amount of SNAN in the omasal and duodenal was significantly increased in the IC group compared with control. Our results are rather similar to that of Choi et al. (2002). The considerable amount of SNAN fractions including peptide and free AA in 
Table 3. Effects of different soluble protein supplements on soluble non-ammonia N (SNAN) concentration in ruminal, omasal, or duodenal digesta of steers (Choi et al., 2012)

\begin{tabular}{|c|c|c|c|c|c|c|c|c|c|c|}
\hline \multirow{2}{*}{ Digesta } & \multirow{2}{*}{ Item } & & \multicolumn{3}{|c|}{$\operatorname{Diet}^{1}$} & \multirow{2}{*}{$\mathrm{SEM}^{2}$} & \multicolumn{4}{|c|}{ Statistical significance $^{3}$} \\
\hline & & & Control & IC & $\mathrm{AHC}$ & & $\mathrm{C} 1$ & $\mathrm{C} 2$ & $\mathrm{C} 3$ & $\mathrm{C} 4$ \\
\hline \multirow{8}{*}{$\begin{array}{l}\text { Ruminal } \\
\text { and omasal }\end{array}$} & Free AA & RD & 47.31 & 45.10 & 47.89 & 1.25 & 0.440 & 0.100 & 0.150 & 0.610 \\
\hline & & OD & 48.23 & 64.21 & 61.92 & 6.06 & 0.070 & 0.790 & 0.090 & 0.140 \\
\hline & Peptide & $\mathrm{RD}$ & 63.72 & 85.74 & 82.53 & 5.23 & 0.020 & 0.670 & 0.020 & 0.040 \\
\hline & & OD & 65.62 & 82.87 & 96.35 & 4.28 & 0.002 & 0.060 & 0.020 & $<0.001$ \\
\hline & Soluble protein & $\mathrm{RD}$ & 20.13 & 18.49 & 20.65 & 1.23 & 0.730 & 0.280 & 0.400 & 0.780 \\
\hline & & OD & 18.79 & 19.16 & 18.72 & 0.88 & 0.850 & 0.620 & 0.680 & 0.930 \\
\hline & SNAN & $\mathrm{RD}$ & 131.15 & 149.33 & 151.08 & 5.31 & 0.030 & 0.820 & 0.060 & 0.050 \\
\hline & & OD & 132.64 & 166.25 & 176.99 & 5.85 & 0.004 & 0.250 & 0.010 & 0.004 \\
\hline \multirow[t]{4}{*}{ Duodenal } & Free AA & & 73.60 & 80.00 & 78.90 & 5.87 & 0.460 & 0.900 & 0.480 & 0.560 \\
\hline & Peptide & & 88.20 & 151.00 & 127.80 & 7.75 & 0.010 & 0.120 & 0.009 & 0.030 \\
\hline & Soluble protein & & 19.30 & 23.40 & 20.70 & 1.38 & 0.180 & 0.240 & 0.100 & 0.510 \\
\hline & SNAN & & 181.00 & 254.40 & 227.40 & 17.18 & 0.060 & 0.340 & 0.050 & 0.140 \\
\hline
\end{tabular}

\footnotetext{
${ }^{1}$ Control = Rice straw+concentrate; $\mathrm{IC}=$ Rice straw+concentrate+intact casein; AHC $=$ Rice straw+concentrate+acid hydrolyzed casein

${ }^{2} \mathrm{SEM}=$ Standard error of the mean.

${ }^{3} \mathrm{C} 1$ = Effect of casein supplements; $\mathrm{C} 2=$ Effect of casein types; $\mathrm{C} 3$ = Effect of intact casein; $\mathrm{C} 4$ = Effect of acid hydrolyzed casein

SNAN $=$ Soluble non-ammonia N. RD = Ruminal digesta. OD $=$ Omasal digesta .
}

the OD from beef cattle was determined in the present study. This may be important as the glucose and/or starch utilization in the small intestine would be increased through soluble protein infusing into the abomasum of beef steers (Richard et al., 2002; Swanson et al., 2002). Richards et al. (2003) reported that starch digestion in the small intestine is more energetically efficient than its fermentation in the rumen.

Increased pancreatic $\alpha$-amylase activity may regulate the type of protein or peptide that flows into the duodenum. In a study on cattle, Taniguchi et al. (1995) suggested that a protein source can improve starch digestion in the bovine small intestine. Furthermore, Richard et al. (2002) reported that abomasal infusion of starch with casein increases starch degradability in the small intestine of steer when compared to starch infusion alone. Moreover, secretion of CCK is known to be stimulated by the disassembled chain peptide and small fraction peptides flowing into the duodenum (Go et al., 1970).

In the present study, our results show that the level of peptide fragments flowing in the duodenum was significantly higher $(\mathrm{p}<0.05)$ upon IC treatment compared to any other treatment (Table 3). Acid hydrolyzed casein (AHC) was composed of $80 \%$ free amino acids, whereas orally administrated intact casein (IC) was composed of the type of peptide fragments commonly found in the small intestine (Table 3).

Many researchers have determined that protein or peptide intake is directly dependent upon the activity of CCK stimulated by peptide fragments flowing into the duodenum in the pancreas (Hara et al., 2000). Therefore, protein hydrolysate flowing into the small intestine is considered to directly stimulate CCK secretion by isolated mucosal cells of the small intestine (Nishi et al., 1998) or STC-1 cells in neurosecretion (Cordier-Bussat et al., 1997). In addition, CCK secretion is involved in the intake level of non-branched-chain amino acids (Hashimoto and Hara, 2004). The proteins supplied to the small intestine of a ruminant are comprised mainly of non-degradable and endogenous secreted proteins (Harmon, 1992).

Thus, our results demonstrated that the type of casein fragments flowing into the small intestine affected the

Table 4. Treatment effects on serum ghrelin, CCK, secretin, insulin and glucose; and duodenum $\alpha$-amylase concentration of Korean native steers

\begin{tabular}{lcccc}
\hline & & Control & Intact casein & Acid hydrolyzed casein \\
\hline Ghrelin & $(\mathrm{ng} / \mathrm{ml})$ & $0.357 \pm 0.1025$ & $0.449 \pm 0.1486$ & $0.417 \pm 0.1484$ \\
CCK & $(\mathrm{ng} / \mathrm{ml})$ & $1.332 \pm 0.3762$ & $2.355 \pm 0.3124^{*}$ & $1.724 \pm 0.4850$ \\
Secretin & $(\mathrm{ng} / \mathrm{ml})$ & $0.949 \pm 0.2695$ & $1.329 \pm 0.2575^{*}$ & $1.155 \pm 0.2956$ \\
Insulin & $(\mathrm{ng} / \mathrm{ml})$ & $0.479 \pm 0.0834$ & $0.537 \pm 0.1177$ & $0.421 \pm 0.0618$ \\
Glucose & $(\mathrm{mg} / \mathrm{dl})$ & $68.400 \pm 2.2301$ & $73.000 \pm 1.2000$ & $73.133 \pm 0.4055$ \\
$\alpha$-Amylase & $(\mathrm{unit} / \mathrm{L})$ & $23.986 \pm 0.8871$ & $26.587 \pm 1.1578^{*}$ & $24.741 \pm 1.5503$ \\
\hline
\end{tabular}

$* \mathrm{p}<0.05$ (Student's paired $t$-test, control $v s$ intact casein). 
regulation of GI hormones (CCK, secretin), which are related to pancreatic $\alpha$-amylase secretion. In our study, although IC and AHC treatments had no effect on serum ghrelin and insulin levels (Table 4), the response patterns of serum ghrelin to IC and AHC treatments were in accordance with secretin in Korean native steers (Figure 2). Ghrelin is a peptide hormone found in the stomach that plays important roles in growth-hormone release and appetite stimulation (Sun et al., 2004). Recently, Itoh et al. (2006) reported that ghrelin injection increases blood CCK concentration. However, Than et al. (2010) showed that injection of secretin into cattle has no effect on the level of ghrelin or growth hormone. Therefore, the relationship between ghrelin and pancreatic $\alpha$-amylase secretion is limited.

The regulatory secretion mechanism of ghrelin in ruminants is thought to involve many complex factors, but information regarding $\alpha$-amylase regulatory secretion of ghrelin and secretin has not been examined in detail until now. In the present study, it was difficult to explain this relationship, although the pattern of serum ghrelin was consistent with that of secretin in steers fed an IC diet. Therefore, further research related to this topic should be performed. There was no change in the level of insulin upon casein administration in the current study (Table 4). In general, glucose promotes the secretion of insulin in the insulin-secreting $\beta$-cells in the pancreas. In this study, however, IC and AHC treatments had no effect on serum glucose level (Table 4). Therefore, it is considered that there was no significant change in the serum insulin level by IC and AHC treatments. This result is similar to those obtained in response to casein injection into the abomasum of lactating dairy cows (Relling and Reynolds, 2008).

In conclusion, this study demonstrated the stimulation of duodenal CCK and secretin in response to IC, resulting in increased pancreatic $\alpha$-amylase secretion. In addition, ghrelin may be associated with GI hormone secretion in Korean native steers.

\section{ACKNOWLEDGEMENTS}

The work was supported by Cooperation Research Project (No. PJ0063722009), Rural Development Administration, Republic of Korea.

\section{REFERENCES}

Chance, R. E., M. Gieszkowski, J. Jaworek, S. J. Konturek, J. Swierczek and J. Tasler. 1981. Effect of pancreatic polypeptide and its C-terminal hexapeptide on meal and secredn induced pancreatic accretion in dogs. J. Physiol. 314:1-9.

Choi, C. W., A. Vanhatalo, S. Ahvenjärvi and P. Huhtanen. 2002. Effects of several protein supplements on flow of soluble nonammonia nitrogen from the forestomach and milk production in dairy cows. Anim. Feed Sci. Technol. 102:15-33.

Choi, C. W., K. H. Kim, S. S. Chang and N. J. Choi. 2012. Soluble non-ammonia nitrogen in ruminal and omasal digesta of Korean native steers supplemented with soluble proteins. Asian Australas. J. Anim. Sci. 25:1269-1275.

Cordier-Bussat, M., C. Bernard, S. Haouche, C. Roche, J. Abello, J. A. Chayvialle and J. C. Cuber. 1997. Peptones stimulate cholecystokinin secretion and gene transcription in the intestinal cell line STC-1. Endocrinology 138:1137-1144.

Croom, W. J. Jr., L. S. Bull and I. L. Taylor. 1992. Regulation of pancreatic exocrine secretion in ruminants: A review. J. Nutr. 122:191-202.

Eastwood, C., K. Maubach, A. J. Kirkup and D. Grundy. 1998. The role of endogenous cholecystokinin in the sensory transduction of luminal nutrient signals in the rat jejunum. Neurosci. Lett. 254:145-148.

Folsch, U. R., A. Oldendorp, P. G. Lankish and W. Creutzfeldt. 1984. European Journal of Clinical Investigation. 14(Suppl): 45.

Go, V. L., A. F. Hofmann and W. H. Summerskill. 1970. Pancreozymin bioassay in man based on pancreatic enzyme secretion: potency of specific amino acids and other digestive products. J. Clin. Invest. 49:1558-1564.

Greenberg, G. R., R. F. McCloy, V. S. Chadwick, T. E. Adrian, J. H. Baron and S. R. Bloom. 1979. Effect of bovine pancreatic polypeptide on basal pancreatic and biliary out puts in man. Dig. Dis. Sci. 24:11-14.

Hara, H., S. Ohyama and T. Hira. 2000. Luminal dietary protein, not amino acids, induces pancreatic protease via CCK in pancreaticobiliary-diverted rats. Am. J. Physiol. 278:937-945.

Harmon, D. L. 1992. Dietary influences on carbohydrases and small intestinal starch hydrolysis capacity in ruminants. J. Nutr. 122:203-210.

Harmon, D. L. and C. C. Taylor. 2005. Factors influencing assimilation of dietary starch in beef and dairy cattle. Proc. Southwest Nutr. Conf. 55-66.

Hashimoto, N. and H. Hara. 2004. Dietary branched-chain amino acids suppress the expression of pancreatic amylase mRNA in rats. Biosci. Biotechnol. Biochem. 68:1067-1072.

Huhtanen, P., P. G. Brotz and L. D. Satter. 1997. Omasal sampling technique for assessing fermentative digestion in the forestomach of dairy cow. J. Anim. Sci. 75:1380-1392.

Itoh, F. A., K. Tokushi, K. Shiro and H. Koichi. 2006. Effects of ghrelin injection on plasma concentrations of glucose, pancreatic hormones and cortisol in Holstein dairy cattle. Comp. Biochem. Physiol. A. Mol. Integr. Physiol. 143:97-102.

Langlois, A., T. Corring, J. C. Cuber, A. M. Gueugneau, F. Levenez and J. A. Chayvialle. 1989. Effects of Pancreatic polypeptide on the pancreatic exocrine secretion stimulated by secretin and cholecystokinin in the conscious pig. Regul. Pept. 24:55-65.

Lin, T. M., D. C. Evans, R. E. Chance and G. F. Spray. 1977. Bovine pancreatic polypeptide: action on gastric and pancreatic secretion in dogs. Am. J. Physiol. 232:311-315.

Li, Y. and C. Owyang. 1993. Vagal afferent pathway mediates physiological action of cholecystokinin on pancreatic enzyme secretion. J. Clin. Invest. 92:418-424.

Manso, M. A., J. I. San Roman, I. de Dios, L. J. Garcia and M. A. Lopez. 1989. Effect of secretin on pancreatic juice proteins in 
caerulein induced acute pancreatitis in the rat. Peptides. 10:255-260.

Meyer, J. H., L. J. Spingola and M. I. Grossman. 1971 Endogenous cholecystokinin potentiates exogenous secretin on pancreas of dog. Am. J. Physiol. 221:742-747.

National Institute of Animal Science (NIAS). 2007. Korean Feeding Standard for Hanwoo. RDA, Suwon.

Nishi, T., H. Hara and T. Kasai. 1998. Guanidinated casein hydrolysate stimulates pancreatic secretagogue release by direct action to the intestine in rats. Proc. Soc. Exp. Biol. Med. 218:357-364

Rausch, U., P. Vasiloudes, K. Rudiger and H. F. Kern. 1985. Invivo stimulation of rat pancreatic acinar cells by infusion of secretin. 1. Changes in enzyme content, pancreatic fine structure and total rate of protein synthesis. Cell Tissue Res. 242:633-639.

Relling, A. E. and C. K. Reynolds. 2008. Abomasal infusion of casein, starch and soybean oil differentially affects plasma concentrations of gut peptides and feed intake in lactating dairy cows. Domest. Anim. Endocrinol. 35:35-45.

Richards, C. J., A. F. Branco, D. W. Bohnert, G. B. Huntington, M. Macari and D. L. Harmon. 2002. Intestinal starch disappearance increased in steers abomasally infused with starch and protein. J. Anim. Sci. 80:3361-3368.

Richards, C. J., K. C. Swanson, S. J. Paton, D. L. Harmon and G. B. Huntington. 2003. Pancreatic exocrine secretion in steers infused post-ruminally with casein and corn starch. J. Anim. Sci. 81:1051-1056.
Sun, Y., P. Wang, H. Zheng and R. G. Smith. 2004. Ghrelin stimulation of growth hormone release and appetite is mediated through the growth hormone secretagogue receptor. PNAS. 101:4679-4684.

Swanson, K. C., J. A. Benson, J. C. Matthews and D. L. Harmone. 2004. Pancreatic exocrine secretion and plasma concentration of some gastrointestinal hormones in response to abomasal infusion of starch hydrolyzate and/or casein. J. Anim. Sci. 82:1781-1787.

Swanson, K. C., J. C. Matthews, C. A. Woods and D. L. Harmon. 2002. Post-ruminal administration of partially hydrolyzed starch and casein influences pancreatic $\alpha$-amylase expression in calves. J. Nutr. 132:376-381.

Tachibana, S., T. Onaga, H. Mineo and S. Kato. 1995. Role of endogenous CCK in regulation of interdigestive pancreatic exocrine secretion in sheep (Ovis aries). Comp. Biochem. Physiol. A. Physiol. 112:103-109.

Taniguchi, K., G. B. Huntington and B. P. Glenn. 1995. Net nutrient flux by visceral tissues of beef steers given abomasal and ruminal infusions of casein and starch. J. Anim. Sci. 73:236-249.

Than Than, S., H. Zhao, S. Yannaing, T. Ishikawa and H. Kuwayama. 2010. Oxyntomodulin increases the concentrations of insulin and glucose in plasma but does not affect ghrelin secretion in Holstein cattle under normal physiological conditions. Domest. Anim. Endocrinol. 39:163170. 